\title{
DETERMINATION OF THERMAL DIFFUSIVITY IN PAPAYA PULPAS A FUNCTION OF MATURATION STAGE ${ }^{1}$
}

\author{
SAVIO FIGUEIRA CORRÊA ${ }^{2}$, MAXIMILIANO SILVADE SOUZA ${ }^{3}$, TALITAPEREIRA ${ }^{4}$, GUSTAVO VERÇOSADE LIMAALVES 5 , \\ JURANDI GONÇALVES DE OLIVEIRA ${ }^{6}$, MARCELO GOMES DA SILVA ${ }^{7}$, HELION VARGAS $^{8}$
}

ABSTRACT - In order to determine the penetration of the thermal wave in the papaya fruit pulp (Carica papaya L.), cv. Golden, thermal diffusivity of the pulp was obtained measuring temperature at four different depths. Measurements were carried out initially with the fruit on the first stage of maturity. The changes of the thermal diffusivity were expressed as a function of ripening. A temporal decrease of the thermal diffusivity was observed. Chemical $(\mathrm{pH}$, soluble solids and total titratable acidity) and physical (pulp firmness) properties were measured as well and the results were compared to the thermal diffusivity change.

Index terms: Carica papaya L.; thermal wavelength; quality parameters.

\section{DETERMINAÇÃO DA DIFUSIVIDADE TÉRMICA DA POLPA DE MAMÃO EM FUNÇÃO DO ESTÁDIO DE MATURAÇÃO}

RESUMO-Para determinar a penetração da onda térmica na polpa do fruto do mamoeiro (Carica papaya L.), cv. Golden, a difusividade térmica foi obtida medindo a temperatura da polpa em quatro diferentes profundidades. As medidas foram realizadas inicialmente no estádio I de maturação do fruto, e as variações da difusividade térmica foram expressas em função do amadurecimento. Foi observada a diminuição da difusividade térmica no tempo. Propriedades químicas ( $\mathrm{pH}$, sólidos solúveis e acidez titulável) e física (firmeza da polpa) também foram determinadas, e os resultados, comparados com as variações da difusividade térmica.

Termos para indexação: Carica papaya L.; comprimento de onda térmica; parâmetros de qualidade.

\section{INTRODUCTION}

To reach the external market (North America and Europe) papaya (Carica papaya L.) must be submitted to a hydrothermal treatment that consists in submerging the fruit in water at $49^{\circ} \mathrm{C}$ during 20 minutes, followed by a second bath at $12{ }^{\circ} \mathrm{C}$ during 15 minutes. The determination of the thermal physics properties of the fruit pulp plays an important role (Sarria and Honório, 2004; Wang et al., 2001) for optimizing the thermal treatment, aiming the reduction of stress in the fruit. Among thermal physics properties, the thermal diffusivity is important mainly because it is directly related to the thermal conductivity of the sample. This parameter is very important and can help to clear, for each specific thermal treatment, how deep is the penetration of the thermal wave in the pulp of the fruit. Also the cooling process of a fruit involves heat transfer processes; and once again the thermal diffusivity presents its importance to describe the possible mechanisms of conductions. Thus, data about the thermal properties of the pulp is very important for instrumentation development and planning types of thermal treatment.
There is a lack of information about the behavior of the pulp thermal properties as function of the fruit maturation stage. During maturation, physical and biochemical changes, involving respectively texture changes (Smith et al., 2003) and biosynthesis of carbohydrates (as well as, their breakdown) (Maness and Perkins-Veazie, 2003) would be responsible for general changes on the thermal properties of the fruit tissues.

Thermal diffusion is a transport phenomenon that takes place when there is a gradient of temperature in a material. A simple linear equation (Fourier's law) describes the flux of energy $\varphi$ throughout a transversal section of a sample:

$$
\varphi=-K\left(\frac{\partial T}{\partial x}\right)
$$

where $\mathrm{K}$ is the thermal conductivity and $\partial \mathrm{T} / \partial \mathrm{x}$ is the gradient of temperature. The negative signal means that heat flows toward the direction of temperature decrease.

Taking into account the conservation of energy, from Equation 1 the following differential equation of the thermal diffusion of heat is obtained (Almond and Patel, 1996):

\footnotetext{
(Trabalho 266-07). Recebido em: 08-11-2007. Aceito para publicação em: 19-06-2008.

${ }^{2}$ Mestre em Ciências Naturais; Laboratório de Ciências Físicas da UENF-CCTA.

${ }^{3}$ Mestrando em Produção Vegetal; Laboratório de Melhoramento Genético Vegetal da UENF-CCTA.

${ }^{4}$ Doutoranda em Ciências Naturais; Laboratório de Ciências Físicas da UENF-CCT.

${ }^{5}$ Bolsista de Iniciação Científica; Laboratório de Ciências Físicas da UENF-CCT.

${ }^{6}$ Professor Associado; Laboratório de Melhoramento Genético Vegetal da UENF-CCTA.

Professor Associado; Laboratório de Ciências Físicas da UENF-CCT;

${ }^{8}$ Professor Titular; Laboratório de Ciências Físicas da UENF-CCT. Av. Alberto Lamego n. 2000, Horto, CEP 28013-602, Campos dos Goytacazes, RJ, Brasil; Tel. /Fax: +55 22 2726-1532. e-mail: mgs@uenf.br.
} 


$$
\left(\frac{\partial T}{\partial t}\right)=\alpha\left(\frac{\partial^{2} T}{\partial x^{2}}\right)
$$

where $\alpha$ is the thermal diffusivity of the material.

Considering as boundary conditions and the periodic heating of the external skin of the fruit, a solution for Equation 2 is:

$$
T=T_{0} e^{-\left(\sqrt{\frac{\omega}{2 \alpha}}\right) x} \operatorname{sen}\left(\omega t-\left(\sqrt{\frac{\omega}{2 \alpha}}\right) x\right)
$$

where $T$ is the temperature in the pulp at the depth $x$ in the time $t$, $T_{0}$, the temperature on the fruit skin, $\omega$ is the angular frequency of the periodic heating and $\alpha$ is the diffusion coefficient of the fruit. The attenuation of the temperature occurs exponentially as a function of the depth by:

$$
\text { Amplitude }=T_{0} e^{-\left(\sqrt{\frac{\omega}{2 \alpha}}\right)}
$$

This type of attenuation defines the effective penetration of the thermal wave into the fruit, $l$, which is known as thermal length:

$$
l=\sqrt{\frac{2 \alpha}{\omega}}
$$

In this work, measurements of the thermal diffusivity of the papaya fruit pulp, in different stages of maturity (stages I, II, III, IV and V), were carried out.

\section{MATERIAL AND METHODS}

\subsection{Sample}

The fruits were provided by a commercial orchard (Caliman Agrícola S. A.), situated in the north of Espírito Santo state (longitude $39^{\circ} 51^{\prime} \mathrm{W}$ and latitude $19^{\circ} 15^{\prime} \mathrm{S}$ ), Brazil. A total of fifteen papaya fruits, cv. Golden, were used. Fruits were harvested regarding to get a homogeneous group with the same stage of maturity. The skin color of fruit was yellow covering less than $15 \%$ of the surface of the skin with the rest of green and the external part of the pulp, about $50 \%$, showed red color. The seeds were mostly mature black. This stage was identified as stage I of maturity. Samples were divided into five groups of three fruits each. Each group was analyzed along five followed days and identified as stage II, III, IV and V, respectively (Folegatti and Matsuura, 2002). The work was performed in the Laboratory of Physics, at the Science and Technology Center, Universidade Estadual do Norte Fluminense Darcy Ribeiro.

\subsection{Thermal diffusion}

Thermal diffusivity of papaya pulp was determined using four thermocouples which were set as different depths $(3,6,9$ and $12 \mathrm{~mm}$ ) and ordered along the meridian region separated by a distance of $10 \mathrm{~mm}$ from each other (Figure 1). In order to avoid the influence of the water bath on the temperature measurements, five glass tubes encapsulating the thermocouples were used. Each sample, initially at room temperature $\left(27 \pm 1^{\circ} \mathrm{C}\right)$, was periodically submerged in two hydrothermal baths (Microquímica Equipamentos Ltda, MQBMP-01) for 20 minutes each, the first at $35.0 \pm 0.1{ }^{\circ} \mathrm{C}$, and the second at $15.0 \pm 0.1{ }^{\circ} \mathrm{C}$. In order to guarantee a radial diffusion of the heat, thus linear in small scale, the sample was completely submerged in water. The alternated submersion was carried out three times, producing a periodical heating of the sample. The values of temperature in the different depths were accomplished in every 30 seconds, using two digital thermometers (Barnant, Model 600-1040).

\section{3. $p H$, soluble solids (SS) and total titratable acidity (TTA)}

In the work, $\mathrm{pH}$ was determined using a digital $\mathrm{pHmeter}$ (WTW, Modelo 330). For each analysis, 30g of pulp were extracted from the equatorial region of the fruit and homogenized in $50 \mathrm{~mL}$ of distilled water. Soluble solids (SS, ${ }^{\circ}$ Brix) were determined using juice from a sub-part of the pulp, by a manual refractometer (ATAGO, Modelo PR-201). The titration method was used to determine the TTA of the fruit pulp using $0.01 \mathrm{~N}$ of $\mathrm{NaOH}$ end point $\mathrm{pH} 8.2$ (AOAC,1984). Results were expressed in citric acid (\%,g/100g pulp).

\subsection{Pulp firmness}

Using a fruit pressure tester (TR Turoni, model 53205) equipped with an $8 \mathrm{~mm}$ probe, the penetration force was determined at three points $(0.5 \mathrm{~cm}$ from the skin $)$ on the fruit pulp (Figure 1). For pulp firmness measurements, fruits were cut into two parts, along its transversal direction.

\section{RESULTS AND DISCUSSION}

The Figure 2 shows the typical temperature behavior for the four different depths in the pulp, for stage I of maturity. The amplitude of the temperature decreases with pulp depth. This result was obtained for the first day of measurement. However, the exponential behavior shown here is in agreement with theoretic curves presented in literature (Teruel et al., 2001; Wang et al., 2001). Some authors have also found a linear temporal increase (Dos Santos, 2004) of the temperature in papaya cv 'Golden', when it was submerged in hydrothermal bath at $48{ }^{\circ} \mathrm{C}$ during 20 minutes.

The Figure 3 shows the dependence of the temperature amplitude on pulp depth for stage I. Average value of three replicates was used. As expected, the intensity of the temperature amplitude decreased when pulp depth increased. Using Equation 4 to fit the results (solid curves in Figure 3), the thermal wavelength was determined and a value equals to $1.61( \pm 0.37)$ $\mathrm{cm}$ was found for Stage I. A period of 40 minutes was used (20 minutes in each thermal bath), representing an angular frequency of $0.0026 \mathrm{~s}^{-1}$. Thus, using Equation 4 thermal diffusivity of the pulp was determined and a value equals to $3.4 \times 10^{-3} \mathrm{~cm}^{2} / \mathrm{s}$ was 
found for Stage I. Similar procedure was applied for the other stages of maturity of the fruit.

As a characteristic of the fruit and its stage of maturity, Figure 4 shows the change of the thermal wavelength and Figure 5 shows the behavior of the thermal diffusivity. The thermal diffusivity for fruit in stage I had a value of $3.4 \times 10^{-3} \mathrm{~cm}^{2} / \mathrm{s}$ and in a linear behavior decreases achieving a value equals to $0.6 \times 10^{-3}$ $\mathrm{cm}^{2} / \mathrm{s}$ on stage V. This decrease of the thermal diffusivity represents a factor of 5.3 and therefore a decrease of the thermal wave penetration of about 2.3 (Equation 5). The observed thermal diffusivity behavior could be explained by changes in the cellular wall components, the integrity of the cellular membranes and in the chemical composition that occurs in the mesocarp during fruit ripening (Brady, 1987). Therefore, the composition of the pulp changes and, in this way, its thermal properties also change.

The pulp thermal diffusivity values found in literature (Hayes, 1984; Hayes and Young, 1989) for processed crushed papaya pulp shows that the value obtained in this work for stage IV, $\alpha=1.21 \pm 0.52 \times 10^{-3} \mathrm{~cm}^{2} / \mathrm{s}$, is very realistic. Also, for other fruit as fig (Sarria and Honório, 2004) and coconut pulp (Etuk et al., $2005)$ the thermal diffusivity is in the range of $10^{-3-} \mathrm{cm}^{2} / \mathrm{s}$.

The Table 1 shows the time dependence of the SS, firmness, $\mathrm{pH}$ and TTA in the fruit. For SS, an average value of $10.13^{\circ}$ Brix was found for the fruit in stage I, which is in agreement with values described for Solo cultivars (Cámara et al., 1993; Fagundes and Yamanishi, 2001; Santana et al., 2004). The results in Table 1 show a linear increase $(p<0.05)$ of soluble solids contents during ripening process, therefore indicating higher sugar concentrations. Although papaya presents only traces of starch, it can have an increment in sugar content as a result of the interconversion of sugars during the fruit ripening (Gomez et al., 2002). Furthermore, an increase of soluble solid content could also be related to the solubility increase of pectin due to action of pectin hydrolytic enzymes during the maturation (Chitarra and Chitarra, 2005). Other authors have observed that by increasing the SS the density and the specific heat increase
(Cavalcanti-Mata et al., 2005). Taking into account that thermal diffusivity is inversely proportional to the density and specific heat (Almond and Patel, 1996; Wang et al., 2001); our results are in accordance to those found in literature.

The SS is also a quality index; its concentration and composition play an important role in fruit taste and suggest its maturation stage. Other parameters as $\mathrm{pH}$ and titratable acidity (TTA) of the pulp are also quality index that reflect the maturity stage of the fruit. The results (Table 1) show that $\mathrm{pH}$ decreased $(p<0.05)$ and TTA did not modify significantly during papaya ripening, which are in agreement with those found in literature (Cámara et al., 1993; Santana et al., 2004).

The firmness of the pulp during ripening was also monitored (Table 1). This fruit quality variable, together with the $\mathrm{SS}$, is the factor that more directly can influence thermal properties of fruit pulp. With the advance in the maturity, the firmness decreases significantly, in a direct relation with the thermal diffusivity of the pulp (Figure 5). The softening of papaya pulp is attributed to the activity of cell wall-degrading enzymes, such as polygalacturonase [PG; EC 3.2.1.67] (Chan et al., 1981; Lazan et al., 1995), pectinmetylesterase [PME; EC 3.1.1.11], $\beta$ galactosidase [GAL; EC 3.2.1.23] (Lazan et al., 1995), and xylanase [XYL; EC 3.2.1.32] (Paull and Chen, 1983). The action of such enzymes decomposes the central lamellae of the cellular wall, reducing the cell-to-cell binding and thus the pulp tissues become soft (Smith et al., 2003). The rupture of cell lamellae that results in a flaccid tissue, promotes a discontinuity in the linking cell to cell (thermal coupling) that modifies the property of thermal diffusion of mesocarp of papaya fruit.

The decrease of the thermal diffusivity is a consequence of the softening of the pulp. As the fruit becomes mature, degradation of the cell wall leads to an increase of its permeability into fluids. This could result in a leak of fluids into intercellular spaces. Aqueous medium produces a decrease of the thermal diffusivity.

TABLE 1 - Quality parameters on the post harvest of papaya fruit for different maturity stages.

\begin{tabular}{ccccc}
\hline \multicolumn{5}{c}{ Quality Parameters* } \\
\hline $\begin{array}{c}\text { Stages of } \\
\text { Maturity }\end{array}$ & SS $\left({ }^{\mathbf{0}}\right.$ Brix $)$ & FIRMNESS (N) & pH & $\begin{array}{c}\text { TTA } \\
(\mathbf{\%}, \mathbf{g} / \mathbf{1 0 0 g} \text { pulp })\end{array}$ \\
\hline I & $10.13 \pm 0.07 \mathrm{E}$ & $76.87 \pm 0.71 \mathrm{~A}$ & $6.14 \pm 0.09 \mathrm{~A}$ & $0.083 \pm 0.001$ \\
II & $10.67 \pm 0.07 \mathrm{D}$ & $47.12 \pm 1.10 \mathrm{~B}$ & $5.81 \pm 0.02 \mathrm{~B}$ & $0.085 \pm 0.003$ \\
III & $11.37 \pm 0.09 \mathrm{C}$ & $29.34 \pm 0.95 \mathrm{C}$ & $5.65 \pm 0.12 \mathrm{BC}$ & $0.087 \pm 0.003$ \\
IV & $12.33 \pm 0.27 \mathrm{~B}$ & $11.28 \pm 2.20 \mathrm{D}$ & $5.53 \pm 0.04 \mathrm{BC}$ & $0.096 \pm 0.007$ \\
V & $12.93 \pm 0.07 \mathrm{~A}$ & $4.63 \pm 1.46 \mathrm{E}$ & $5.39 \pm 0.02 \mathrm{C}$ & $0.100 \pm 0.009$ \\
\hline
\end{tabular}

* Mean of three replicates $( \pm \mathrm{SD})$ separation within columns by Tukey’s multiple range test, $p<0.05$, $(\mathrm{n}=3)$. TTA not significant for test $\mathrm{F}, p<0.05$. SS - soluble solids (SS)

TTA - total titratable acidity 


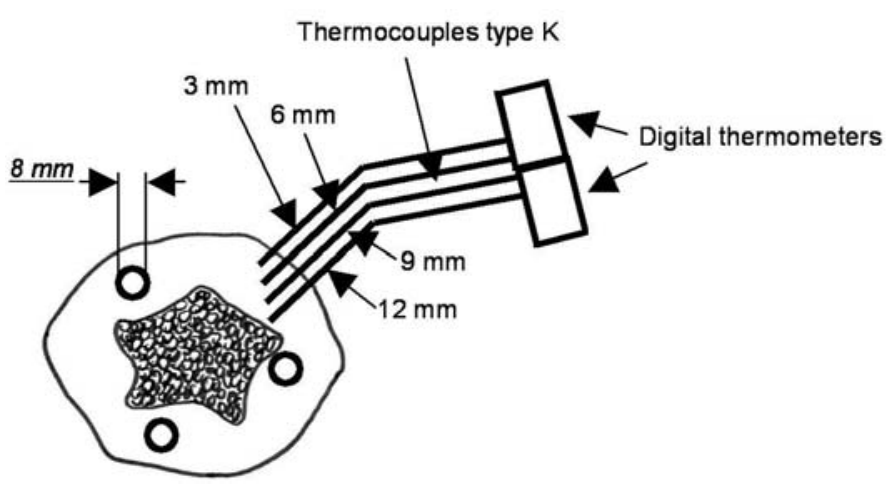

FIGURE 1 - The disposition of the thermocouples inside fruit pulp and three fruit pressure tester points.

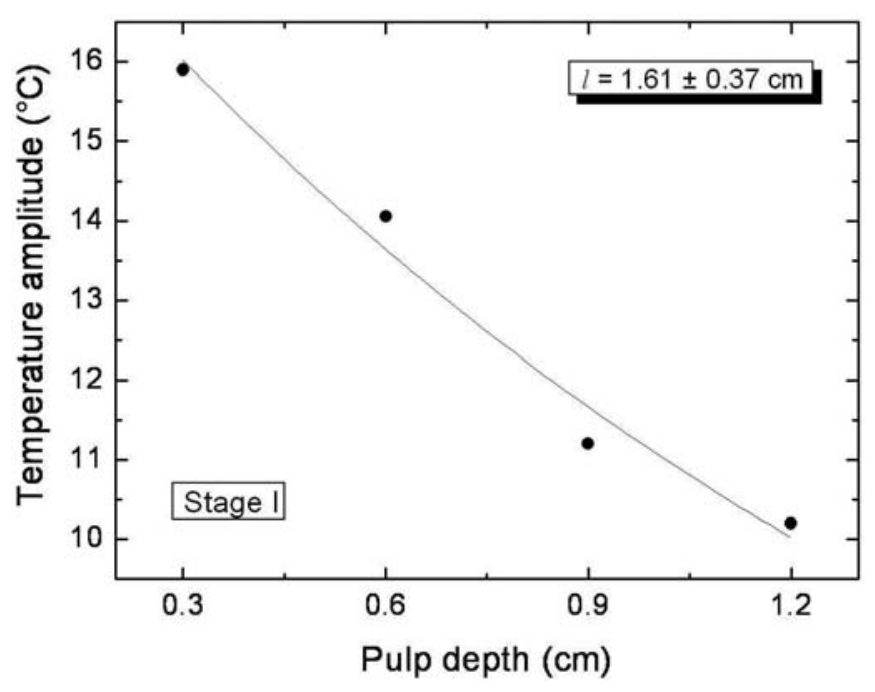

FIGURE 3 - The temperature amplitude dependence on the pulp depth for stage III of maturity. Values are presented as the average of three replicates.

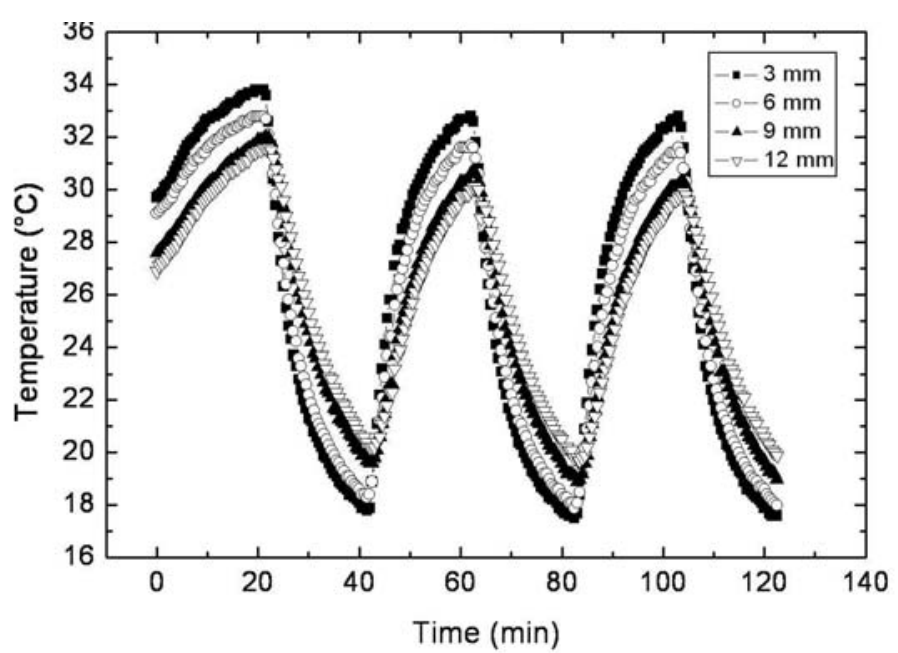

FIGURE 2 - The time dependence of temperature for four different depths in the pulp.

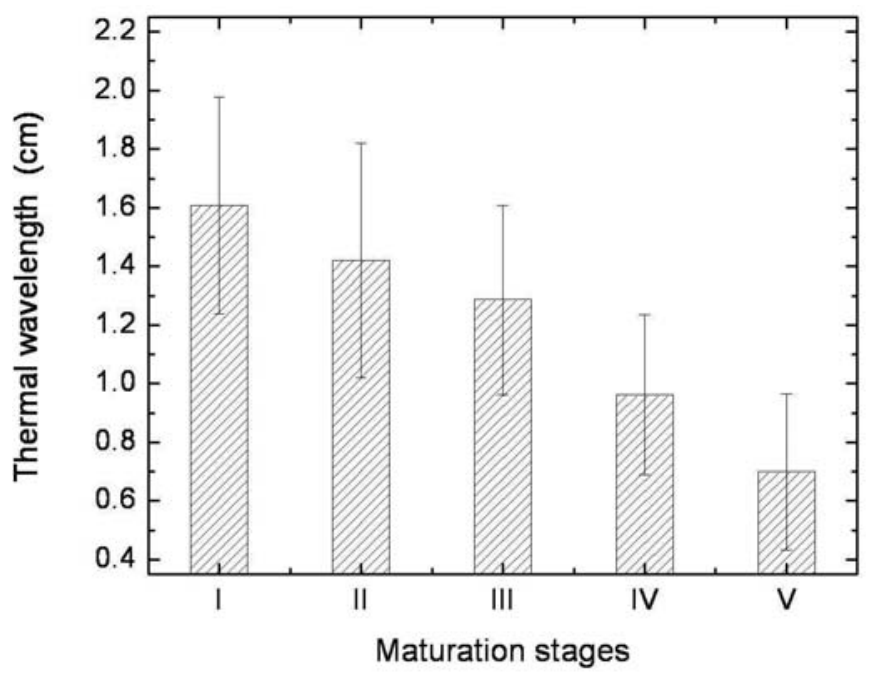

FIGURE 4 - The thermal wavelength as a function of the fruit stage of maturity. Values are presented as the average of three replicates.

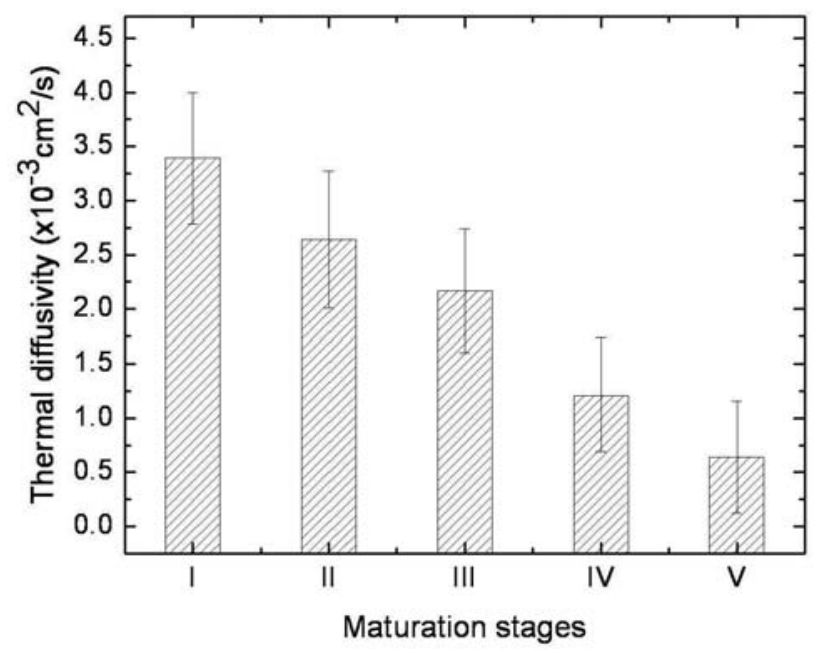

FIGURE 5 - The thermal diffusivity as a function of the fruit stage of maturity. Values are presented as the average of three repetitions. 


\section{CONCLUSION}

The method used to determine thermal diffusivity of the pulp was feasible, showing good results for papaya fruit. The maturation process induced to a structural disarrangement of the mesocarp tissues leading to an integrity reduction of the cell wall and cell membrane. This effect culminated in a small retention of intracellular substances, which are launched into the intercellular space affecting the thermal diffusivity. Furthermore, during the maturation the increase of the soluble solid content resulted in a decrease of the thermal diffusivity.

\section{ACKNOWLEDGMENT}

This work was financially supported by CNPq, FINEP and Caliman Agrícola S/A.

\section{REFERENCES}

ALMOND, D.P.; PATEL, P.M. Photothermal science and technique. London: Chapman \& Hall, 1996. 204p.

BRADY, C. J. Fruit ripening. Annual Review of Plant Physiology, Palo Alto, v.38, p.155-178, 1987.

CÁMARA, M. M.; DÍEZ, C.; TORIJA, M. E. Changes during ripening of papaya fruit in different storage systems. Food Chemistry, Kidlington, v.46, p.81-84., 1993.

CAVALCANTI-MATA, M.E. R. M.; DUARTE, M.E. M.;ZANINI, H. L. H. T. Calor específico e densidade da polpa de cajá (Spondias lutea L.) em diferentes concentrações de sólidos solúveis sob baixa temperatura. Engenharia Agrícola, Jaboticabal, v.25, p.488$498,2005$.

CHAN, H. T.; TAM, S.; SEO, S. T. Papaya polygalacturonase and its role in thermally injured ripening fruit. Journal of Food Science, Chicago, v.46, p. 190-197, 1981.

CHITARRA, M. I. F.; CHITARRA, A. B. Pós-colheita de frutas e hortaliças: fisiologia e manuseio. 2.ed. Lavras: Editora UFLA, 2005. 785p.

ETUK, S.E.; AKPABIO, L.E.; AKPABIO, K.E. Determination of thermal properties of Cocos nucifera trunk for predicting temperature variation with its thickness. Arabian Journal for Science and Engineering, Dhahran, v. 30, p. 121-126, 2005

FAGUNDES, G.R.; YAMANISHI, O.K. Características físicas e químicas de frutos de mamoeiro do grupo 'solo' comercializados em 4 estabelecimentos de Brasília-DF. Revista Brasileira de Fruticultura, Jaboticabal, v. 23, n. 3, p. 541-545, 2001.

FOLEGATTI, M.I.S.; MATSUURA, F.C.A.U.(Ed.). Mamão póscolheita. Brasília: Embrapa Informações Tecnológicas, 2002. 59p.
GOMEZ, M.; LAJOLO, E.; CORDENUNSI, B. Evolution of soluble sugars during ripening of papaya fruit and its relation to sweet taste. Journal of Food Science, Chicago, v.67, p.442-447, 2002.

HAYES, C.F. Thermal diffusivity of papaya fruit (Carica papaya L., Var. Solo). Journal of Food Science, Lanham, v.49, p.12191221, 1984.

HAYES, C.F.; YOUNG, H. Extension of model to predict survival from heat treatment of papaya infested with oriental fruit flies (Diptera: Tephritidae). Journal Economic Entomology, Lanham, v.82, p.1157-1160, 1989.

LAZAN, H.; SELAMAT, M.K.; ALI, Z.M. $\beta$-galactosidase, polygalacturonase and pectinesterase in differential softening and cell wall modification during papaya fruit ripening. Physiologia Planarum, Copenhagem, v.95, p.106-112, 1995.

MANESS, N.; PERKINS-VEAZIE, P. Soluble and Storage Carbohydrates. In. Bartz, J. A., Brecht, J. K. (Ed.). Postharvest physiology and pathology of vegetables. New York: Marcel Dekker, 2003. p. 361-382.

PAULL. R. E.; CHEN, N. J. Postharvest variation in cell walldegradating enzymes of papaya (Carica papaya $\mathrm{L}$.) during fruit ripening. Plant Physiology, Bethesda, v.72, p.382-385, 1983.

SANTANA, L. R. R.; MATSUURA, F. C. A. U.; CARDOSO, R. L. Genótipos melhorados de mamão (Carica papaya L.): avaliação sensorial e físico-química dos frutos. Ciência e Tecnologia de Alimentos, Campinas, v. 24, p. 217-222, 2004.

SANTOS, A. E. O. dos. Características físicas na pós-colheita do mamão tratado termicamente em sistema de fluxo hidráulico contínuo. 2004. 51 f. Dissertação (Mestrado) - Universidade Federal de Viçosa, Viçosa, 2004.

SARRIA, S. D.; HONÓRIO, S. L. Condutividade e difusividade térmica do figo (Fícus carica L.) "Roxo de Valinhos". Engenharia Agrícola, Jaboticabal, v.24, p.185-194, 2004.

SMITH, A. C.; WALDRON, K.W.; MANESS, N.; PERKINSVEAZIE, P. Vegetable texture: measurement and structural implications. In. Bartz, J.; Brecht, J.K. (Ed.). Postharvest physiology and pathology of vegetables. New York: Marcel Dekker, 2003. p. 297-369.

TERUEL, B.; CORTEZ, L. A.; LEAL, P.; LIMA, A. G. B. Estudo teórico do resfriamento com ar forçado de frutas de geometrias diferentes. Ciência e Tecnologia de Alimentos, Campinas, v.21, p.228-235, 2001.

WANG, S.; TANG, J.; CAVALIERI, R. P. Modeling fruit internal heating rates for hot air and hot water treatments. Postharvest Biology and Technology, Wageningen v. 22, p. 257-270, 2001. 